\title{
Sustainability Challenges in Professional Football: The Destructive Effects of the Society of the Spectacle
}

\author{
Gilles Paché ${ }^{1}$ \\ ${ }^{1}$ CRET-LOG, Aix-Marseille University, Aix-en-Provence, France \\ Correspondence: Professor Gilles Paché, CRET-LOG, Aix-Marseille University, 413 Avenue Gaston Berger, \\ 13625 Aix-en-Provence Cedex, France. Tel: 1-33-(0)4-42-93-90-26. E-mail: gilles.pache@univ-amu.fr
}

Received: September 25, 2019

Accepted: December 3, 2019 Online Published: January 30, 2020

doi:10.5539/jsd.v13n1p85

URL: https://doi.org/10.5539/jsd.v13n1p85

\begin{abstract}
For a long time considered as a simple means of entertainment, football (soccer) has now become a main element of the society of the spectacle, with huge economic and financial stakes. A series of competitions are managed to generate significant revenues shared by international institutions (including FIFA), private companies and star players. This paper points out that professional football is engaged in a headlong rush, including the irrational use of non-renewable resources and frantic consumption among fans, especially of licensed merchandise. Dialogue between football stakeholders and the advocates of sustainability has become difficult, as evidenced by the conditions under which the 2022 FIFA World Cup will take place in Qatar, with three major controversies: initial controversies in the choice of host country; environmental controversies about stadium air conditioning; and future controversies regarding the importance of sustainability in the allocation of the next FIFA World Cups.
\end{abstract}

Keywords: air conditioning, consumption, football (soccer), resources, spectacle, un-sustainability, 2022 FIFA World Cup

\section{Introduction}

Professional football (soccer) has become a major entertainment industry, both economically and socially. Major events, such as the FIFA World Cup or the UEFA Champions League in Europe, involve huge financial interests involving TV networks, powerful sponsors and private investors for whom the objective is to maximize revenues from football competitions. In addition, the professional football market is now based on a new globalized model, breaking out of the former model entrenched in local territories. Only relatively recently, football competitions were national or even regional, with a rational use of relatively limited human and financial resources (they were provided by spectators attending matches). Today, football competitions are established on a continental or even worldwide scale, with the unlimited use of human and financial resources. For example, massive fan movements are planned to amortize the infrastructures, and the number of matches is multiplied with the same objective. Consequently, we are in a typical situation of unlimited activity growth in a world with limited resources.

This paper's objective is to focus on an economic context that has been widely studied in sports economics, sociology or marketing, but which has never been addressed (to our knowledge) from a perspective of sustainability. Some research focuses on the sustainability of mega-events, but it does not address the dramatic effects of the headlong rush towards globalized competitions using more and more non-renewable resources. One of the most significant case is the 2022 FIFA World Cup to be held in Qatar. Many observers highlighted the way in which Qatar obtained the right to organize the competition, with clear suspicions of corruption, or the difficult working conditions imposed on immigrant workers (close to enslavement). We must also include the enormous investments to be made, the optimal use of which is not even guaranteed after the competition. For example, given the extreme heat conditions, 12 air-conditioned stadiums are being built or renovated, with a device to cool the atmosphere in 30 minutes. The case of the Qatari FIFA World Cup is symbolic of the "Dubai syndrome," as well as the difficulties for dialogue between the stakeholders of globalized football and the advocates of sustainability.

To understand why this dialogue is now becoming difficult, this paper is organized into two sections. The first section highlights professional football's real breakthrough in the 1970s, as it entered into the era of the society of the spectacle as defined by Debord (1967/2014). The financing of clubs is profoundly changing, increasing 
TV rights and commercial revenues. Under these conditions, a club will only be successful if it is media-based, and if it presents itself as a powerful brand capable of triggering frantic consumption among fans (Lee, 2005). One of the most dramatic results is the totally irrational use of non-renewable resources, which the second section illustrates with the 2022 FIFA World Cup to be held in Qatar. Awarding the competition to this Arabian country, whose climatic conditions are very unfavorable to the practice of high-level football, triggered a wave of criticism regarding the completely un-sustainable nature of the mega-event. It shows to what extent all the madness in the world is now crystallizing around a sport that is certainly popular but plagued by seemingly limitless financial appetites.

\section{Conceptual Framework}

As in any industry, owners of professional football clubs seek to ensure the durability of their organization by controlling, as much as possible, the variables of their direct and indirect environment. However, competition between clubs takes place at two different levels. The first level, purely sporting, establishes hierarchies based on uncertain sporting results; each year, events such as the French Cup or the English Cup allow teams with a reputation for being inferior, or even having amateur status, to shine against powerful teams. The second level, of a strategic nature, concerns the fierce competition between the most prestigious clubs, often on a continental European scale, to maximize the amount of non-ticketing revenue. It is obviously this second level that is now of crucial importance from a managerial perspective. Large amounts of non-ticketing revenue means that even in a critical situation of poor results for several seasons, leading to a less favorable position in the sports hierarchy, as long as the TV rights and commercial revenue themselves remain high a club with a good reputation will be able to continue to develop.

\subsection{Financing Perspective}

Football analysts now recognize the need to distinguish between ticketing, on the one hand, and TV rights and commercial TV revenue, on the other, when looking at the economics of professional football (Minquet, 2004; Goddard and Sloane, 2014; Bond and Addesa, 2019). Ticketing is linked to the presence of spectators in the stadium on the day of the match (including year-round subscriptions), with some clubs having succeeded in stabilizing a large portion of ticketing revenue by sometimes selling more than $80 \%$ of the seats all year round; this transforms a variable revenue into a fixed revenue, regardless of the sporting performance throughout the season. TV rights and commercial revenue, on the other hand, correspond to revenue from broadcasting rights negotiated with TV networks, sponsorship from large and medium-sized companies and merchandising. The objective of club owners is clearly to increase the share of non-ticketing revenue, which is a stable support of cash flow (Minquet, 2004; Campa Planas and Kalemba, 2017). This means that the club has become such a strong brand that it will be able to keep loyal fans regardless of the sporting results.

It is impossible to understand the situation without a historical perspective. The evolution of professional football, especially since its extraordinary development in the 1970s, underlines the shift from one governance model to another. Andreff (2005) thus refers to the succession of two management models, the first based on financing clubs through municipal subsidies and ticketing, the second based on financing clubs through marketing activities and TV rights. Table 1 underlines the decreasing importance of traditional municipal subsidies for TV rights and commercial income since the early 1970s, with ticketing now accounting for around $10 \%$ of the funding of French League 1 clubs. Adopting a broader vision that encompasses all professional sports, Fontanel (2007) also advocates the existence of an evolutionary model at several different stages, each time the transition from one to the other being a critical moment in terms of the club's survival, a model in which the logic behind financing the activity is transformed. It is therefore through non-ticketing revenue, and only through this, that clubs can continue to grow (Frick, 2020).

Table 1. Evolution of revenue distribution in the French League 1 (1970-2016, in \%)

\begin{tabular}{lcccccccccc}
\hline & $\mathbf{1 9 7 0 -}$ & $\mathbf{1 9 7 5 -}$ & $\mathbf{1 9 8 0 -}$ & $\mathbf{1 9 8 5 -}$ & $\mathbf{1 9 9 0 -}$ & $\mathbf{1 9 9 5 -}$ & $\mathbf{2 0 0 0 -}$ & $\mathbf{2 0 0 5 -}$ & $\mathbf{2 0 1 0 -}$ & $\mathbf{2 0 1 5 -}$ \\
& $\mathbf{1 9 7 1}$ & $\mathbf{1 9 7 6}$ & $\mathbf{1 9 8 1}$ & $\mathbf{1 9 8 6}$ & $\mathbf{1 9 9 1}$ & $\mathbf{1 9 9 6}$ & $\mathbf{2 0 0 1}$ & $\mathbf{2 0 0 6}$ & $\mathbf{2 0 1 1}$ & $\mathbf{2 0 1 6}$ \\
\hline Ticketing & 81 & 62 & 65 & 50 & 29 & 24 & 16 & 15 & 13 & 11 \\
Commercial & 1 & 9 & 14 & 22 & 26 & 28 & 29 & 25 & 27 & 44 \\
TV rights & 0 & 0 & 1 & 7 & 21 & 31 & 51 & 57 & 58 & 45 \\
Subsidies & 18 & 29 & 20 & 21 & 24 & 17 & 4 & 3 & 2 & - \\
\hline
\end{tabular}

Source: Adapted from Andreff (2005) and DNCG annual reports. 
The most powerful clubs in Europe have naturally chosen to collect a maximum amount of revenue from TV rights and commercial revenue, as shown in Figure 1, leading to innovative competition/cooperation strategies between clubs to increase the amount of these revenues. In France, the most famous example is that of Bernard Tapie, the president of the Olympique de Marseille. Pérès et al. (2007) prove that Olympique de Marseille and Paris Saint-Germain built a fierce rivalry between the two clubs from scratch just to revive the media's interest in a League 1 that was then crushed by Olympique de Marseille's domination. Olympique de Marseille's domination led to a gradual reduction in the number of TV viewers, tired of the lack of suspense regarding the outcome of the competition, which might lead to a defection of some sponsors and a reduction in TV rights. The artificially maintained rivalry between Olympique de Marseille and Paris Saint-Germain, replicated from the Real Madrid/Barcelona FC classico in Spain, boosted interest in professional football in France, to the direct benefit of the two clubs, which have shared part of the massive increase in TV rights. Debord's analysis (1967/2014) of the society of the spectacle takes on its full meaning here when the author indicates that in this society, all social relations between individuals are intended to be mediated by images. In the case of Olympique de Marseille and Paris Saint-Germain, it was the media's coverage of the opposition between an arrogant and elitist France (Paris) versus a rebellious France challenging the established order (Marseille).

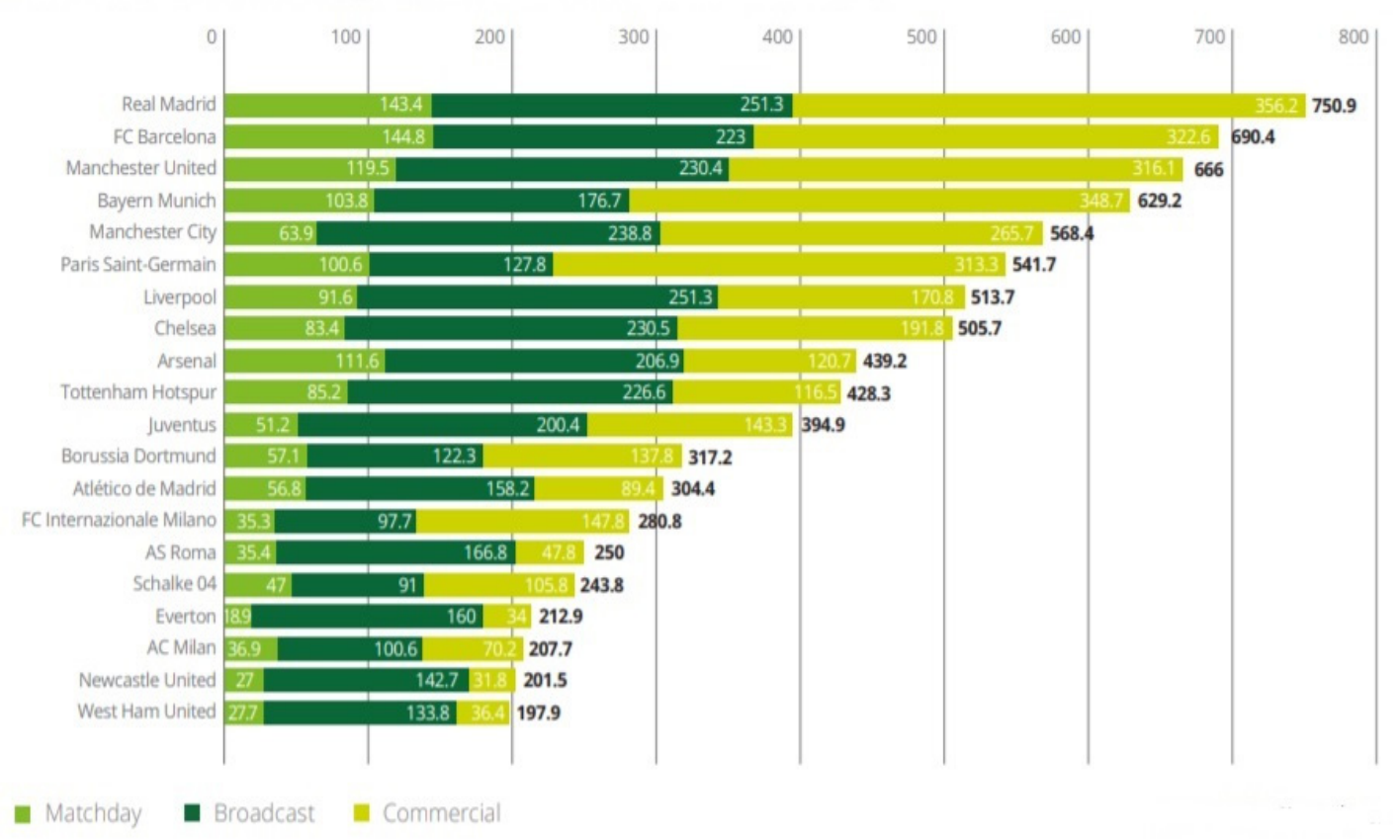

Figure 1. Football money league' top 20 in Europe (2017-2018, in millions $€)$

Source: Deloitte (2019).

\section{2 "Marketisation" Perspective}

Until quite recently, professional football was first and foremost a game for connoisseurs, comparing the advantages and disadvantages of game systems during heated discussions over a whiskey, assessing a player's technical ability and questioning the collective logic to be put in place to achieve the best possible sporting results. In brief, aesthetic and ecstatic dimensions of football are the roots of a true passion (Tuncel, 2017). Moreover, the attachment to football on behalf of connoisseurs translates into an immoderate and exclusive love for a single club and/or national team, sometimes throughout a lifetime. The best illustration of this is in the autobiographical novel Fever Pitch by Nick Hornby, a well-known English journalist (Hornby, 1992). The author tells of his devouring passion for the Arsenal club since a famous day in May 1968 when his father took him to see the Arsenal/Stoke City match. From then on, football would take a central place in Nick Hornby's life and the Arsenal stadium would be the site of many of his learning experiences: learning life alongside the club's proletarian supporters, learning geography by following his favorite team on the move, but also learning about love through the seductive relationships maintained, as teenagers and young adults, in the stadium tribunes. 
For true connoisseurs, and even more so for the most ardent fans, attachment to a football club has a sentimental dimension, independent of necessarily random sporting results (Molina Luque, 2002), that develops a true social interaction based on norms and membership values (Djalal, 2015). The attachment and creation of an emotional bond between the club and the fans results in a massive consumption of licensed merchandise (Busse and Damiano, 2019). Nevertheless, this consumption is symbolic in nature, in order to mark the group's commitment to values: for some observers, it is in this respect that it is possible to say that football is a sacred and iconic experience (Derbaix and Decrop, 2011; Fulconis and Paché, 2014; McDonagh, 2017). Such an approach no longer satisfies the owners of professional football clubs, whose priority is now to maximize non-ticketing revenue in a context of making investments more profitable. Professional football is indeed part of the society of the spectacle (Tomlinson, 2002; Martins Barreira, 2014), matches are a unique show that must include a leader product in order to sell a brand image and its associated licensed merchandise (Szymoszowskyj et al., 2016). The annual report on the most valuable football brands (42 clubs over the planet) published in May 2019 by Brand Finance, an independent brand valuation consultancy, states that $47 \%$ of the fans purchase an official replica club shirt, $26 \%$ purchase a new shirt every season or every two seasons, and $28 \%$ purchase products and/or services from their favorite club's sponsor brand (Brand Finance, 2019). Figure 2, taken from Stride et al. (2020), shows a strong development of replica shirt wearing as a matchday fashion in the 1990s, when professional football really entered the era of the society of the spectacle.

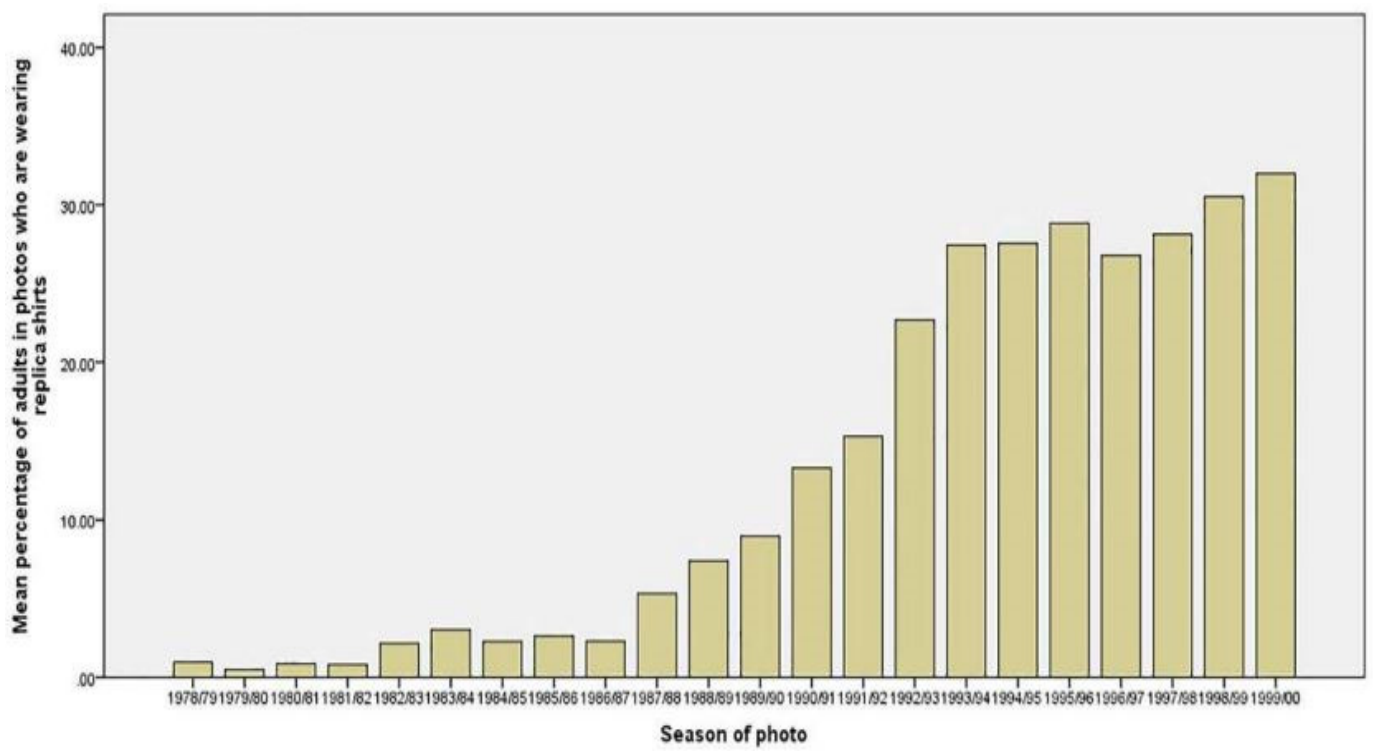

Figure 2. Average proportion of adult fans in crowd scenes wearing replica football shirts (matchday)

Source: Stride et al. (2020).

Beyond licensed merchandise sales, why become a brand for a club? The answer is twofold according to Richelieu and Desbordes (2009). Firstly, because professional sports teams create an emotional attachment with the consumer, stronger than in any other industry. Secondly, exploiting its brand can allow a team to position itself in relation to other sports clubs on the market, develop and strengthen fan loyalty, and generate additional revenue, which has become very important in the context of the salary boom in professional sports. One of the most recent developments is the implementation of experiential strategies whose objective is to stage the football match and boost "marketisation" (Bodet et al., 2018), as companies stage their brands to develop consumption relationships. To do this, the clubs seek to awaken the senses of the fans (consumers) by playing on music and sight, in other words, to produce atmospheres at the match (Edensor, 2015). More and more professional clubs are organizing true pre-match entertainment, with lights, banners and smoke, both on the field and in the stadium tribunes. The creation of a memorable experience is also based on the presence of fan zones, a major place of social interaction between spectators. This makes them actors of their own experience and allows to keep a good memory of the match, regardless of the score (and the eventual defeat of the team).

Grundy (2004) thus demonstrates how, at the turn of the 1980s, English clubs decided, by mutual agreement, to radically transform the organization and governance of professional football in order to enable it to become a truly family show and generate high revenue. With the objective of significantly increasing sales revenue, a 
major action plan was launched: improving stadium comfort (disappearance of non-seated seats), completely securing the premises to eradicate the recurrent violence of hooligans, etc. In doing so, the clubs sought to emancipate themselves from their traditional clientele based on loyal fans, i.e. people involved in the unconditional support for their team. Simple consumers of entertainment, with low loyalty, i.e. those who simply enjoy excitement and go to the stadium as they would to a rock concert, represent a remarkable potential for income regardless of the sporting results. To do this, building a strong brand image and ensuring a memorable experience are essential for developing frantic consumption, which is one of the major characteristics of football today. However, it should be noted that the transformation of professional football into a show is a strategy that has been widely used in North American leagues for decades. Consequently, as early as 1876, the National League of Baseball forced clubs to build stadiums that had to be designed to accommodate families: the sale of alcohol was prohibited, schedules and fees were adapted to their expectations, violence was severely repressed (Bancel et al., 2019).

\section{The 2022 FIFA World Cup Case}

While club owners have understood that TV rights and commercial revenue are an essential element of development and profitability, this is also the case for FIFA, particularly in its management of the various FIFA World Cups. Thus, for the 2014 FIFA World Cup in Brazil alone, out of a revenue of US $\$ 4.83$ billion, only US\$527 million was derived from ticketing, or just over 10\%, compared to US $\$ 2.42$ billion in TV rights, or 58\%. This has constantly progressed over the past several FIFA World Cups, which confirms that football has become a key component in the society of the spectacle. FIFA's latest financial report, published in 2019, confirms this major development with a real "explosion" of revenues from TV broadcasting rights and marketing rights between 2015 and 2018 (see Table 2). The vertigo caused by these figures testifies to an undeniable economic reality: football offers an unexpected showcase for sponsors looking for maximum media exposure to develop new markets and increase their sales even further. While this reality is widely known by sports economics specialists, the 2022 FIFA World Cup, organized by Qatar, underlines how much the destructive effects of professional football now seems limitless, and in total denial of the indispensable and rational use of scarce resources.

Table 2. FIFA revenue split 2015-2018 (US\$ million)

\begin{tabular}{lccccc}
\hline & $\mathbf{2 0 1 5}$ & $\mathbf{2 0 1 6}$ & $\mathbf{2 0 1 7}$ & $\mathbf{2 0 1 8}$ & Total \\
\hline TV broadcasting rights & 258 & 96 & 229 & 2,544 & $\mathbf{3 , 1 2 7}$ \\
Marketing rights & 157 & 115 & 245 & 1,143 & $\mathbf{1 , 6 6 0}$ \\
Licensing rights & 51 & 204 & 160 & 185 & $\mathbf{6 0 0}$ \\
Hospitality/accommodation rights \& ticket sales & 0 & 0 & 23 & 689 & $\mathbf{7 1 2}$ \\
Other revenue & 78 & 87 & 77 & 80 & $\mathbf{3 2 2}$ \\
\hline Total & $\mathbf{5 4 4}$ & $\mathbf{5 0 2}$ & $\mathbf{7 3 4}$ & $\mathbf{4 , 6 4 1}$ & $\mathbf{6 , 4 2 1}$ \\
\hline
\end{tabular}

Source: 2018 FIFA financial report (2019).

\subsection{Initial Controversies}

To everyone's surprise, on December 2, 2010, FIFA's executive committee designated Qatar as the host country for the 2022 FIFA World Cup. At first glance, some observers believed that this was a real political and strategic endeavor to develop football in a region as populated and fervently passionate about the sport as the Middle East. In addition, Qatar has been developing a modern transport organization for several years to manage the huge number of fans expected for the 2022 FIFA World Cup: Doha has an efficient rapid transit bus (BRT) system, as well as a $212 \mathrm{~km}$ metro with 85 stations (Azzali, 2017). Very quickly, however, multiple controversies cast doubt on the relevance of FIFA's choice, especially since other countries with much more developed sports facilities were also on the list (notably the United States and Japan). The competition, which will take place from November 21 to December 18, 2022, in one of the richest countries in the world, is being held albeit three main areas of uncertainty:

- Recurrent suspicions of corruption. A contract proposal was reportedly sent to FIFA 21 days before the vote on December 2, 2010, providing for the payment of US $\$ 400$ million in TV rights by Al-Jazeera. Of this amount, US $\$ 100$ million would have been earmarked for "TV production costs," costs that are usually $100 \%$ borne by FIFA. A second transaction between FIFA and Qatar was reportedly concluded shortly thereafter, with an additional payment of US $\$ 480$ million, as part of another TV rights contract. Such 
practices amount to corruption, according to FIFA's own rules: they stipulate that no financial proposal related to the organization of a FIFA World Cup can be proposed by the candidates in the running. The president at the time, the inflammatory Sepp Blatter, reportedly signed the contract a week after awarding the competition to Qatar. In brief, we can speak about persistent challenges to the integrity of the 2022 FIFA World Cup bid (Dorsey, 2015).

- Strategies to destabilize competing candidates. Qatar is also accused of trying to discredit other bids to host the 2022 FIFA World Cup, including paying a public relations team to spread false information about Australia and the United States, its main rivals in the campaign to award the competition. Having been prohibited from communicating on opposing bids, both positively and negatively, as stipulated in FIFA's guidelines, Qatar would then have adopted a backdoor strategy, a common manipulation in sports mega-events bidding process (Matheson et al., 2018). This would have consisted in recruiting influential individuals to attack the offers in their countries of origin, giving the impression that there was no support among the population to host the FIFA World Cup. This lack of popular support is almost eliminatory since FIFA makes it one of the determining criteria when awarding the competition.

- Deplorable working conditions for migrant workers. Lastly, the disastrous management of immigrant staff, mainly from the Indian sub-continent, has given rise to a large number of complaints from international organizations and NGOs. This is due to longer working hours, without taking into account the heatwave, particularly low wages given the difficulty of the tasks, the persistence of residence visas, and especially the existence of the famous kafāla, where all employment contracts must be sponsored by a Qatari citizen, assimilated to modern slavery (ter Haar, 2018). Under pressure, Qatar decided at the end of 2016 to gradually dismantle the kafäla, but issues relating to the respect of workers' rights continue, particularly with regards to wages going unpaid for several months. Under the new law, immigrant workers still need their employer's permission to leave the country, but a commission has been implemented to deal quickly with complaints from people who are prevented from leaving the country.

However, the most ferocious criticism comes from the choice of a geographical area marked by weather conditions unsuited to the practice of top-level football; as underlined by Loxston et al. (2019), hard environmental conditions directly impact technical match-play characteristics. The 2019 IAAF World Championships, held in Doha from September 27 to October 6, 2019, confirm this point. Thus, the marathon runners had to brave the suffocating heat, with a felt temperature of $45^{\circ} \mathrm{C}$, which led to a number of dropouts never seen before during an international competition. Traditionally, the various FIFA World Cups are scheduled every four years at the end of the European and South American championship seasons, between June and July. The minimum outside temperature in Qatar is then $30^{\circ} \mathrm{C}$, but it can reach a felt temperature of $45^{\circ} \mathrm{C}$, like during the 2019 IAAF World Championships (the absolute record being a real temperature of $53^{\circ} \mathrm{C}$ ). FIFA has therefore imposed on the various national federations to move the 2022 FIFA World Cup to November and December, at a time when temperatures are only around $25^{\circ} \mathrm{C}$, forcing all European leagues to introduce a break of at least seven weeks in their own championships. Nevertheless, it became clear that an air conditioning system for each stadium would be necessary to prevent players from suffocating on the pitch. Qatar has therefore had to build or renovate a set of 12 stadiums with climate-controlled conditions to meet FIFA's requirements, ignoring any ecological considerations.

\subsection{Environmental Controversies}

For Dobrovolska (2018, p. 71), to refer to the sustainable socio-economic development of a country means knowing whether "the growing material and spiritual needs of the population are satisfied; rational and ecologically safe management and highly efficient use of natural resources are provided; maintenance of natural and ecological living conditions favorable to human health, preservation, reproduction and enhancement of the quality of the environment and the natural and resource potential of social production are ensured." It is clear that Qatar, and in particular the 2022 FIFA World Cup organized by the country, is a typical example of the absence of sustainable socio-economic development, the first victims of which are immigrant workers $(80 \%$ of the total population of 2.6 million inhabitants, from India, Iran, Pakistan, Iraq, Nepal, Bangladesh and Sri Lanka). If the growing material and spiritual needs of this immigrant population are far from being satisfied, it is more generally the country that suffers from devasting ecological living conditions linked to industrialization process (Ekhlas and Bary, 2018).

According to the World Bank, Qatar is the country that emits the most $\mathrm{CO}_{2}$ per capita into the atmosphere on Earth: about 45.4 tons per capita in 2014, while the world average is 5.0 tons per capita. This is due to a very energy-intensive lifestyle (and consumption), which Qatari policymakers have not yet been able to regulate to 
improve environmental quality (Charfeddine et al., 2018), even though the country is engaged in a major program of new building construction, rather than the renovation of old buildings, which is expected to reduce $\mathrm{CO}_{2}$ emissions by about 2.3 million tons by 2050 (Harmon and Truby, 2019; Kamal et al., 2019). The 2022 FIFA World Cup raises questions that continue along the lines of what we could call the "Dubai syndrome." Thus, the 12 stadiums built or renovated, listed in Table 3, testify to an architectural exuberance and an overstatement in the iconic use of the image as a media weapon against neighboring countries. This is even truer since the beginning of the diplomatic crisis between Saudi Arabia and Qatar in June 2017, with the threat of creating the Salwa channel that would transform Qatar into an island. In the face of these tensions, it appears that Qatar wishes to use the 2022 FIFA World Cup to build a balance of "soft power" that is favorable in a geopolitical perspective (Henderson, 2014; Brannagan and Giulianotti, 2018; Grix et al., 2019), which explicitly refers to the essence of Debord's society of the spectacle (1967/2014).

Table 3. The stadiums built or renovated for the 2022 FIFA World Cup

\begin{tabular}{cccc}
\hline City & Name of the stadium & Capacity & Status \\
\hline & Doha Port St. & 45,000 & Construction \\
& Education City St. & 45,300 & Construction \\
Doha & Khalifa International St. & 40,000 & Renovation \\
& Qatar University St. & 43,500 & Construction \\
& Sports City St. & 47,500 & Construction \\
& Thani bin Jassim St. & 44,700 & Renovation \\
\hline Al-Khôr & Al-Khwar St. & 45,300 & Construction \\
Ar Rayyân & Ahmed bin Ali St. & 40,000 & Renovation \\
Al-Wakrah & Al-Wakrah St. & 44,700 & Construction \\
Ash Shamal & Ash Shamal St. & 45,100 & Construction \\
Lusail & Lusail Iconic St. & 86,200 & Construction \\
Umm Salal & Umm Salal St. & 45,100 & Construction \\
\hline
\end{tabular}

Source: The author.

If architectural exuberance can be analyzed as a simple commercial showcase, with a limited impact on the environment, the same cannot be said for how stadiums function. Indeed, the use of these 12 stadiums will repeatedly encounter the problem of how to cool down the air, which, by nature, generates significant energy costs. A report from the International Energy Agency (IEA) points out that 1.6 billion air conditioners were installed worldwide in 2016, and 135 million new units are sold each year (IEA, 2018). As large consumers of electricity that is still largely produced by coal-fired power plants, with a strong increase since 1990 (see Table 4), air conditioners are responsible for rising temperatures in large urban centers as they release heat outdoors in order to cool a home or office. According to IEA projections, the number of air conditioners is expected to reach 5.6 billion by 2050 , leading to a doubling of greenhouse gas emissions between 2016 and 2050, adding an additional 1 billion tons of $\mathrm{CO}_{2}$ to the atmosphere per year. Qatar has certainly sought to develop clever solutions to reduce energy costs associated with cooling stadiums. For example, the Doha Port Stadium is built on an artificial peninsula, which allows the surrounding waters of the Persian Gulf to supply the air conditioning system. As for Al-Khawr Stadium, its roof is in the form of a shell with a canvas, an architectural technique designed to facilitate air circulation. However, these solutions cannot cover all air cooling-related needs.

Table 4. Cooling energy use in buildings around the Earth

\begin{tabular}{lccccccc}
\hline TW/h equivalents & $\mathbf{1 9 9 0}$ & $\mathbf{1 9 9 5}$ & $\mathbf{2 0 0 0}$ & $\mathbf{2 0 0 5}$ & $\mathbf{2 0 1 0}$ & $\mathbf{2 0 1 5}$ & $\mathbf{2 0 1 6}$ \\
\hline Electricity & 592.10 & 700.83 & 944.25 & $1,308.50$ & $1,568.44$ & $1,830.76$ & $1,996.66$ \\
Natural gas & 15.59 & 25.38 & 31.93 & 35.46 & 33.27 & 26.70 & 25.24 \\
\hline
\end{tabular}

Source: Adapted from IEA (2018).

Indeed, stadium air conditioning systems are mainly based on solar panels, but their efficiency will certainly require the development of significant areas in order to create sufficient comfort both for players and for the 
more than 500,000 seats available within the 12 stadiums. Sofotasiou et al. (2015) conducted dynamic thermal modeling to assess air conditioning needs and ensure compliance with both the heat stress index and the aero-thermal comfort thresholds. It appears that for each of the matches in the competition, $115 \mathrm{MW} / \mathrm{h}$ needs to be consumed in order to provide comfortable conditions both indoors and out. An estimate of $1,000 \mathrm{~km}^{2}$ of solar panels seems realistic in order to meet air conditioning requirements, which represents one tenth of Qatar's total surface area $\left(11,437 \mathrm{~km}^{2}\right)$. Transferred to the scale of France, this would mean covering more than the entire Midi-Pyrénées region (Toulouse and Montpellier areas) with solar panels. Therefore, there is no doubt that $\mathrm{CO}_{2}$-emitting energy sources will be needed to cool the stadiums, unless Qatar turns to the Barakah nuclear power plant in the United Arab Emirates.

\subsection{Future Controversies}

Consequently, we can see that the occasionally mentioned idea of an ecological 2022 FIFA World Cup is unrealistic, despite a number of spectacular advertisements, and the funding of research programs whose aim is to globally promote the ideology of a sustainable vision for Qatar 2022. One example is the National Priority Research Program (NPRP), funded by the Qatar National Research Fund (QNRF), which provided the contribution of Hayajneh et al. (2017). The authors take care to detail the environmental protection considerations within contracts, and much of their paper is based on an almost advertorial presentation of the "green stadiums." One of the most effective advertising devices remains the presence of "dismountable stadiums" after the competition, which has given rise to a great many positive comments on websites. However, there is only one stadium built with recycled materials (including sea containers) that will be completely dismountable, transportable and reusable within several sports and cultural arenas and, therefore, it will still be necessary to find regular uses for the almost 500,000 places left in a country without a championship or a national team worthy of the name.

Will the 2022 FIFA World Cup experience fundamentally transform FIFA's governance? In a rather critical article, Campelli (2018) points out that if FIFA wants to change the rules of the game in the allocation of the next FIFA World Cups, the environmental dimension will probably continue to be considered as minor. To demonstrate transparency, FIFA now relies on working groups to evaluate the various proposals made to host the 2026 competition (in terms of meeting expectations and minimizing technical and financial risks). However, the nine main technical evaluation criteria take into account stadiums, teams and referee facilities, accommodation, transport, IT\&T, FIFA fan fest, organizing costs, ticketing/hospitality revenues and media/marketing revenues. In the bidding process, "sustainability" explicitly appears only at the stadium level (with "accessibility"), and in an extremely low proportion compared to stadium capacity and technical installations (see Figure 3). It is therefore to be feared that the environmental dimension will remain for FIFA a subtle green washing strategy without jeopardizing the foundations of the society of the spectacle.

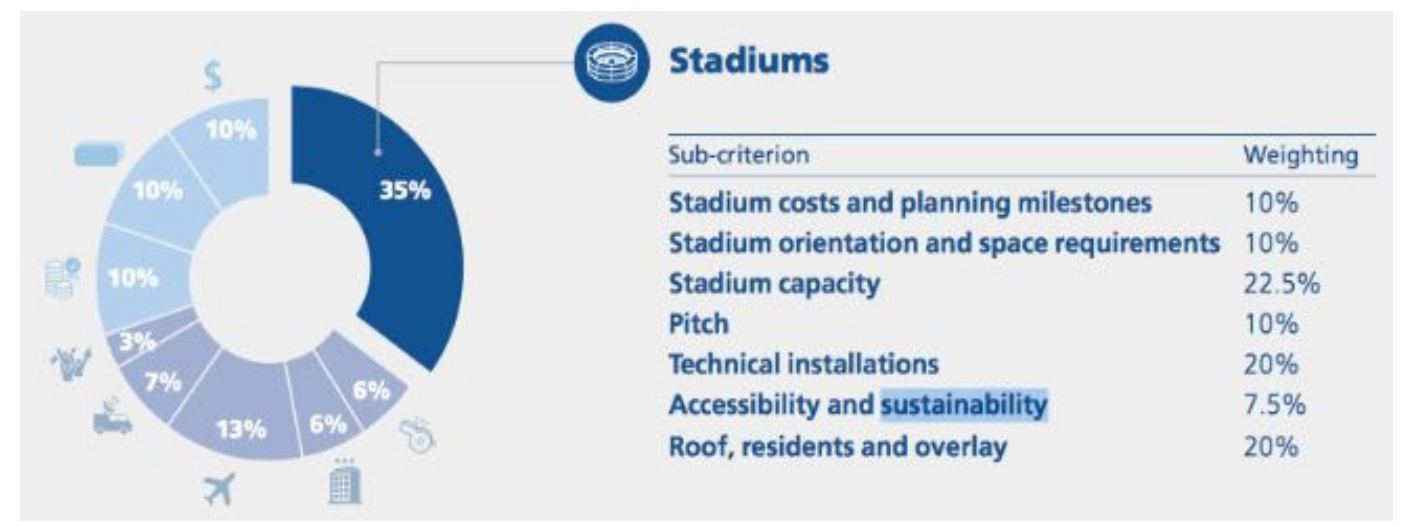

Figure 3. The low weight of sustainability criterion in the World Cup bidding process

Source: Campelli (2018).

\section{Conclusion}

We should not draw too hasty of a conclusion from the case of the 2022 FIFA World Cup in Qatar by condemning a country that has simply taken advantage of an opportunity to shine on the international stage. 
Moreover, corruption and influence have undoubtedly undermined the attribution of other FIFA World Cups without FIFA being dragged into the scandal. The 2022 FIFA World Cup is simply an almost idealized representation of the society of the spectacle, it underlines the destructive madness that professional football carries in its irrational use of the planet's resources. Frantic consumption is pushed to its peak when the most prestigious clubs take care, every year, to completely update their equipment and push the most determined fans to buy the latest jerseys from the upcoming season. This example of planned obsolescence deserves to be analyzed in depth to demystify a universal sport that constantly attracts crowds, especially younger generations. Of course, sustainable initiatives are moving in the right direction (Francis et al., 2017), even if they remain anecdotal. For example, in April 2019, a football field designed from 50,000 recycled cups was inaugurated in Sochi (Russia). The sports facility, known as the ReCup Arena, was built by one of FIFA's official sponsors, Budweiser, who recycled cups used during the 2018 FIFA World Cup.

\subsection{Critical Analysis of Mega-Sport Events}

Policymakers working to implement a circular economy approach are an excellent development; these policies are perfectly linked to energy-economizing solutions, which are the foundation of contemporary sustainable strategies and, more generally, ecological industry (Guo et al., 2010). Similarly, thinking about the green legacy of mega-events is positive (Preuss, 2013), although it is always necessary to identify the gap between discourse and reality, as Gaffney (2013) underlines in his analysis of the planning of the Rio de Janeiro Olympic Games in 2016. In a rather innovative way, several studies are now being developed regarding the possibilities of reducing the carbon footprint associated with a mega-event, particularly in terms of transportation of event participants and visitors between the source and host countries. The model suggested by Pereira et al. (2017) concludes that the emergence of more sustainable mega-events, such as a sustainable FIFA World Cup, will be further facilitated by the fact that a decision regarding a host country should be made after the team qualification round, rather than before. Unfortunately, it is very likely that the choice of a host country will depend mainly on geopolitical considerations, rather than environmental dimensions, and it is hard to imagine FIFA, or any other professional football club, making decisions with the collective welfare in mind, when the financial stakes are so high for their shareholders. Under these circumstances, unless there are limitations imposed on professional football by governmental or inter-governmental structures, the mad rush to oversize and overuse scarce resources will continue in the coming years.

\subsection{Research Avenues}

While professional football can be considered an excellent example of the society of the spectacle, it is possible to extend the analysis to other activities, such as the organization of rock or rap festivals or world tours of international musical groups. In both cases, there is an excessive use of scarce resources and major environmental damage. They are as much linked to the organization of the events themselves as to the movements of the fans. Perhaps one of the most significant ecological disasters is the Woodstock Festival in August 1969 (Salaun, 2018), with the largest traffic jam in US history up to now, three deaths due to a lack of health facilities, the non-existence of a cleaning system and the declaration of "disaster area" on the second day of the Festival. Even if this case is exceptional, it indicates that the excesses of the society of the spectacle have a universalist dimension in their destructive effects. Ultimately, the "stadium tours" regularly organized by rock groups such as the Rolling Stones probably look like the FIFA World Cups and justify an original research program in a sustainable perspective.

\section{Acknowledgments}

The author sincerely thanks two anonymous reviewers of the Journal of Sustainable Development for their insightful comments on a previous version of the paper. The findings achieved herein are solely the responsibility of the author.

\section{References}

Andreff, W. (2005). The financial crisis in French soccer: about a French Senate report. Proceedings of the $7^{\text {th }}$ Annual Conference of the International Association of Sport Economists. Ottawa, 1-31 (CD-rom). Retrieved from https://www.researchgate.net/publication/24131337

Azzali, S. (2017). Public transport in the Gulf region: is the development of a BRT system a viable option for Doha? Journal of Sustainable Development, 10(6), 234-240. https://doi.org/10.5539/jsd.v10n6p234

Bancel, F., Belgodère, B., \& Philippe, H. (2019). Créer de la valeur dans le football: comment évaluer les clubs et leurs actifs. Paris: RB Edition. 
Bodet, G., Kenyon, J., \& Ferrand, A. (2018). Appetite for or resistance to consumption relationships? A trans-European perspective on the marketisation of football fan relationships. Journal of Consumer Culture, 18(2), 317-335. https://doi.org/10.1177/1469540517747092

Bond, A.-J., \& Addesa, F. (2019). TV demand for the Italian Serie A: star power or competitive intensity? Economics Bulletin, 39(3), 2110-2116.

Brand Finance (2019). Football 50. London. Retrieved from https://brandfinance.com/

Brannagan, P.-M., \& Giulianotti, R. (2018). The soft power-soft disempowerment nexus: the case of Qatar. International Affairs, 94(5), 1139-1157. https://doi.org/10.1093/ia/iiy125

Busse, R., \& Damiano, J.-P. (2019). The role of commercialisation of the European football business for the emotional bond between fans and clubs. Advances in Management, 12(1), 8-29. Retrieved from https://search.proquest.com/openview/2a60b773a580001a42362594f67f18c0/

Campa Planas, F., \& Kalemba, N. (2017). Managing sporting success and economic efficiency in the professional football: identification of determinant factors through the academic literature. European Accounting \& Management Review, 3(2), 45-64. https://doi.org/10.26595/eamr.2014.3.2.3

Campelli, M. (2018). How important is sustainability to the World Cup bidding process? Sport Sustainability Journal, June 6. Retrieved from https://sportsustainabilityjournal.com/

Charfeddine, L., Al-Malk, A.-Y., \& Al Korbi, K. (2018). Is it possible to improve environmental quality without reducing economic growth: evidence from the Qatar economy. Renewable \& Sustainable Energy Reviews, 82, 25-39. https://doi.org/10.1016/j.rser.2017.09.001

Debord, G. (1967/2014). The society of the spectacle. Berkeley (CA): Bureau of Public Secrets.

Derbaix, C., \& Decrop, A. (2011). Colours and scarves: an ethnographic account of football fans and their paraphernalia. Leisure Studies, 30(3), 271-291. https://doi.org/10.1080/02614367.2010.527356

Djalal, D. (2015). The socio-economic value of sports: strengthening social capital through football. Journal of Sustainable Development, 8(6), 16-30. https://doi.org/10.5539/jsd.v8n6p16

Dobrovolska, O. (2018). Contemporary paradigm of sustainable development: the evolution of formation and development. Environmental Economics, 9(1), 69-82. https://doi:10.21511/ee.09(1).2018.06

Dorsey, J. (2015). How Qatar is its own worst enemy. International Journal of the History of Sport, 32(3), 422-439. https://doi.org/10.1080/09523367.2015.1008212

Ederson, T. (2015). Producing atmospheres at the match: fan cultures, commercialisation and mood management in English football. Emotion, Space \& Society, 15, 82-89. https://doi.org/10.1016/j.emospa.2013.12.010

Ekhlas, M.-M., \& Bary, A. (2018). Qatar's perception of climate change and meeting the challenges. Environment \& Ecology Research, 6(5), 479-486. https://doi.org/10.13189/eer.2018.060508

Fontanel, G. (2007). Les transformations structurelles des clubs sportifs: recherche d'un cadre d'analyse approprié à leur gestion. Unpublished doctoral dissertation, Lyon University.

Francis, T., Norris, J., \& Brinkmann, R. (2017). Sustainability initiatives in professional soccer. Soccer \& Society, 18(2-3), 396-406. https://doi.org/10.1080/14660970.2016.1166769

Frick, B. (2020). Conquering the pitch: the economics of soccer. Cham: Springer.

Fulconis, F., \& Paché, G. (2014). Football passion as a religion: the four dimensions of a sacred experience. Society \& Business Review, 9(2), 166-185. https://doi.org/10.1108/SBR-09-2013-0064

Gaffney, C. (2013). Between discourse and reality: the un-sustainability of mega-event planning. Sustainability, 5(9), 3926-3940. https://doi.org/10.3390/su5093926

Goddard, J., \& Sloane, P., Eds. (2014). Handbook on the economics of professional football. Cheltenham: Edward Elgar Publishing. https://doi.org/10.4337/9781781003176

Grix, J., Brannagan, P., \& Lee, D. (2019). Entering the global arena: emerging states, soft power strategies and sports mega-events. Singapore: Palgrave Pivot. https://doi.org/10.1007/978-981-13-7952-9

Grundy, T. (2004). Strategy and financial management in the football industry. Strategic Change, 13(8), 405-422. https://doi.org/10.1002/jsc.696

Guo, J., Mao, H., \& Wang, T. (2010). Ecological industry: a sustainable economy developing pattern. Journal of Sustainable Development, 3(3), 239-242. 
Harmon, A., \& Truby, J. (2019). Achieving green building in Qatar through legal and fiscal tools. Journal of Sustainable Development, 12(5), 96-111. https://doi.org/10.5539/jsd.v12n5p96

Hayajneh, A., Elbarrawy, H., El Shazly, Y., \& Rashid, T. (2017). Football and sustainability in the desert, Qatar 2022 green World Cup's stadiums: legal perspective. European Journal of Social Sciences, 55(4), 475-493. Retrieved from https://www.europeanjournalofsocialsciences.com/issues/PDF/EJSS_55_4_09.pdf

Henderson, J. (2014). Hosting the 2022 FIFA World Cup: opportunities and challenges for Qatar. Journal of Sport \& Tourism, 19(3-4), 281-298. https://doi.org/10.1080/14775085.2015.1133316

Hornby, N. (1992). Fever pitch. London: Victor Gollancz.

International Energy Agency [IEA]. (2018). The future of cooling: opportunities for energy-efficient air conditioning. Paris.

Kamal, A., Al-Ghamdi, S., \& Koç, M. (2019). Role of energy efficiency policies on energy consumption and $\mathrm{CO}_{2}$ emissions for building stock in Qatar. Journal of Cleaner Production, 235, 1409-1424. https://doi.org/10.1016/j.jclepro.2019.06.296

Lee, F. (2005). Spectacle and fandom: media discourse in two soccer events in Hong Kong. Sociology of Sport Journal, 22(2), 194-213. https://doi.org/10.1123/ssj.22.2.194

Loxston, C., Lawson, M., \& Unnithan, V. (2019). Does environmental heat stress impact physical and technical match-play characteristics in football? Science \& Medicine in Football, 3(3), 191-197. https://doi.org/10.1080/24733938.2019.1566763

Martins Barreira, M. (2014). An aesthetic conceptual approach to soccer. Discusiones Filosóficas, 15(25), 15-29. Retrieved from http://ref.scielo.org/8qv7g5

Matheson, V., Schwab, D., \& Koval, P. (2018). Corruption in the bidding, construction and organisation of mega-events: an analysis of the Olympics and World Cup. In Breuer, M., \& Forrest, D. (Eds.), The Palgrave handbook on the economics of manipulation in sport (pp. 257-278). Cham: Palgrave Macmillan. https://doi.org/10.1007/978-3-319-77389-6_14

McDonagh, P. (2017). Football-Marketplace icon? Consumption Markets \& Culture, 20(1), 7-11. https://doi.org/10.1080/10253866.2016.1163944

Minquet, J. (2004). Sports, football et finance. Revue Française de Gestion, 150, 141-160. https://doi.org/10.3166/rfg.150.141-160

Molina Luque, F. (2002). Le profil sociologique des amateurs de football: adhésions identitaires et fidélisation. Revue STAPS, 57, 69-84. https://doi.org/10.3917/sta.057.0069

Pereira, R., Camara, M., Ribeiro, G., \& Filimonau, V. (2017). Applying the facility location problem model for selection of more climate benign mega sporting event hosts: a case of the FIFA World Cups. Journal of Cleaner Production, 159, 147-157. https://doi.org/10.1016/j.jclepro.2017.05.053

Pérès, J.-F., Riolo, D., \& Aiello, D. (2007). OM-PSG, PSG-OM, les meilleurs ennemis: enquête sur une rivalité (2nd ed.). Paris: Mango Sport.

Preuss, H. (2013). The contribution of the FIFA World Cup and the Olympic Games to green economy. Sustainability, 5(8), 3581-3600. https://doi.org/10.3390/su5083581

Richelieu, A., \& Desbordes, M. (2009). Football teams going international-The strategic leverage of branding. Journal of Sponsorship, 3(1), 10-22.

Salaun, V. (2018). La logistique événementielle: des opérations à la stratégie. Une illustration par le festival de Woodstock. Actes du Congrès National de la Recherche en IUT 2018, Aix-en-Provence, 1-3 (CD-rom). Retrieved from https://hal-univ-lemans.archives-ouvertes.fr/hal-02153157v1

Sofotasiou, P., Hughes, B., \& Calautit, J. (2015). Qatar 2022: facing the FIFA World Cup climatic and legacy challenges. Sustainable Cities \& Society, 14, 16-30. https://doi.org/10.1016/j.scs.2014.07.007

Stride, C., Catley, N., \& Headland, J. (2020). Shirt tales: how adults adopted the replica football kit. Sport in History, 40(1), 106-146. https://doi.org/10.1080/17460263.2019.1578255

Szymoszowskyj, A., Winand, M., Kolyperas, D., \& Sparks, L. (2016). Professional football clubs retail branding strategies. Sport, Business \& Management: An International Journal, 6(5), 579-598. https://doi.org/10.1108/SBM-09-2016-0048 
ter Haar, B. (2018). FIFA, Qatar, kafäla: can the World Cup create a better world of work? International Labor Rights Case Law, 4(1), 128-132. https://doi.org/10.1163/24056901-00401019

Tomlinson, A. (2002). Theorising spectacle: beyond Debord. In Sugden, J., \& Tomlinson, A. (Eds.), Power games: a critical sociology of sport (pp. 44-60). London: Routledge.

Tuncel, Y. (2017). The aesthetic and ecstatic dimensions of soccer: towards a philosophy of soccer. Soccer \& Society, 18(2-3), 181-187. https://doi.org/10.1080/14660970.2016.1166781

\section{Copyrights}

Copyright for this article is retained by the author(s), with first publication rights granted to the journal.

This is an open-access article distributed under the terms and conditions of the Creative Commons Attribution license (http://creativecommons.org/licenses/by/4.0/). 